\title{
Comparative Study of the Fife and Drum Blues Traditions of Othar Turner and the Preservation, Development, and Innovation of Sharde Thomas and the Rising Stars Fife and Drum Band
}

Donnie Ryan Jobe

drj0009@mix.wvu.edu

Follow this and additional works at: https://researchrepository.wvu.edu/etd

Part of the Musicology Commons

\footnotetext{
Recommended Citation

Jobe, Donnie Ryan, "Comparative Study of the Fife and Drum Blues Traditions of Othar Turner and the Preservation, Development, and Innovation of Sharde Thomas and the Rising Stars Fife and Drum Band" (2020). Graduate Theses, Dissertations, and Problem Reports. 7559.

https://researchrepository.wvu.edu/etd/7559

This Thesis is protected by copyright and/or related rights. It has been brought to you by the The Research Repository @ WVU with permission from the rights-holder(s). You are free to use this Thesis in any way that is permitted by the copyright and related rights legislation that applies to your use. For other uses you must obtain permission from the rights-holder(s) directly, unless additional rights are indicated by a Creative Commons license in the record and/ or on the work itself. This Thesis has been accepted for inclusion in WVU Graduate Theses, Dissertations, and Problem Reports collection by an authorized administrator of The Research Repository @ WVU. For more information, please contact researchrepository@mail.wvu.edu.
} 
Comparative Study of the Fife and Drum Blues Traditions of Othar Turner and the Preservation, Development, and Innovation of Sharde Thomas and the Rising Stars Fife and Drum Band

Donnie Ryan Jobe 
Comparative Study of the Fife and Drum Blues Traditions of Othar Turner and the Preservation, Development, and Innovation of Sharde Thomas and the Rising Stars Fife and Drum Band

Donnie R. Jobe

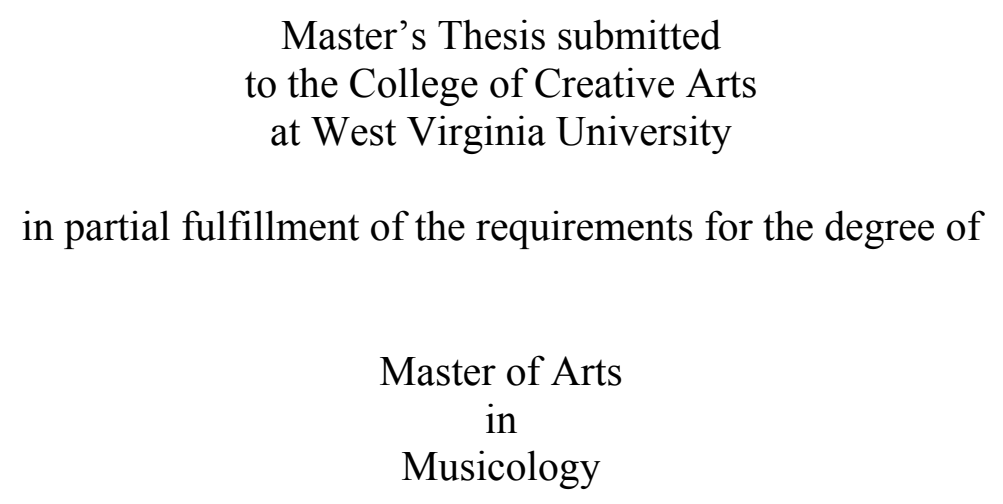

Michael Vercelli, D.M.A., Chair

Matthew Heap, Ph.D.

Travis Stimeling, Ph.D.

School of Music

Morgantown, West Virginia

2020

Keywords: Othar Turner, Sharde Thomas, Fife and Drum Blues, Heritage Copyright 2020 Donnie R. Jobe 


\begin{abstract}
Comparative Study of the Fife and Drum Blues Traditions of Othar Turner and the Preservation, Development, and Innovation of Sharde Thomas and the Rising Stars Fife and Drum Band

Donnie R. Jobe

Othar Turner held the Fife and Drum Blues traditions of North Mississippi for decades. Since his passing in 2003, his granddaughter Sharde Thomas has taken over as the keeper of these traditions. The musical characteristics of Othar are still present in Sharde's music today, however her interpretations have shaped these current traditions. This research discusses heritage and folklore theories of scholars Rodney Harrison, Martha Sims, and Martine Stephens as a lens to evaluate Sharde's musical interpretations and compares them to Othar's last recordings before his passing. This document provides a model for how these musical characteristics and interpretations relate and shape heritage.
\end{abstract}




\section{Acknowledgments}

I would first like to thank Sharde Thomas and Chris Mallory for helping me receive the Shawty Blues album. Next, I would like to thank Dr. Michael Vercelli for advising me and guiding me on this project. Also, thank you to Dr. Travis Stimeling and Dr. Matthew Heap for being a part of my committee. I am extremely grateful to all the faculty and staff at WVU for pushing me in my academics. Thanks to my parents, family, and friends for their love and support. Lastly, and most importantly, I want to thank my Lord and Savior Jesus Christ for His grace and mercy and for allowing me to do what I do. 
Table of Contents

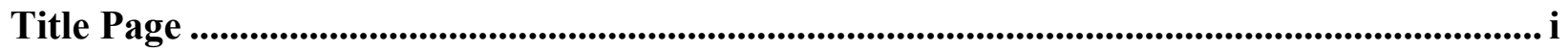

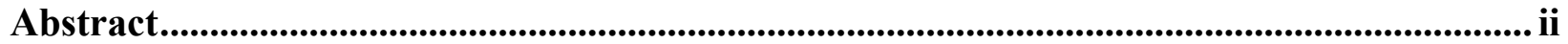

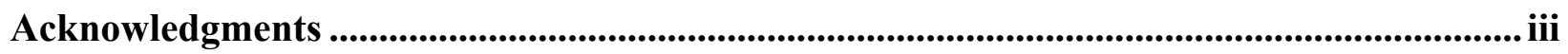

Table of Contents..............................................................................iv

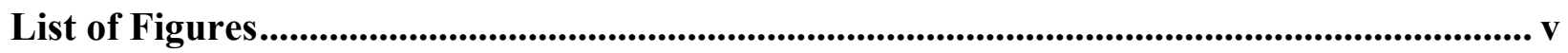

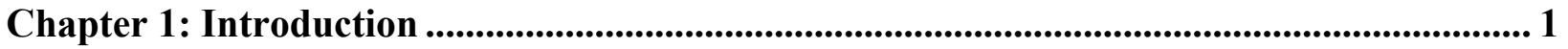

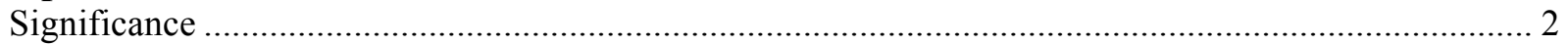

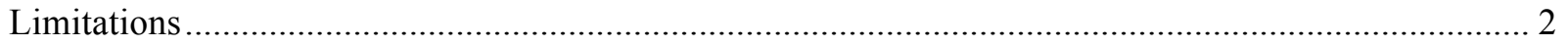

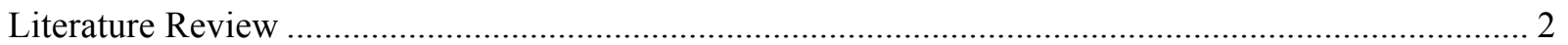

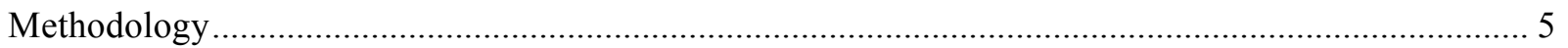

Chapter 2: Heritage and its Application to the Music of Sharde Thomas ............................... 7

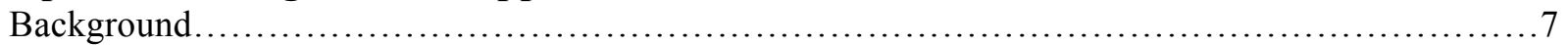

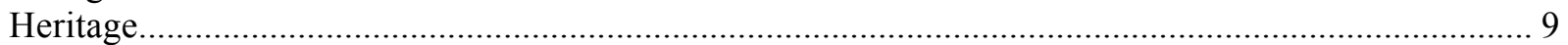

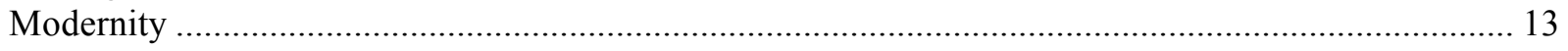

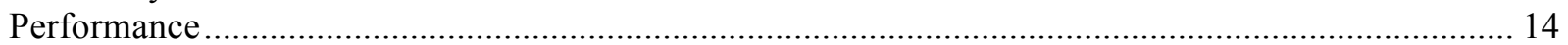

Chapter 3: Musical Description of Othar Turner and Sharde Thomas ............................... 18

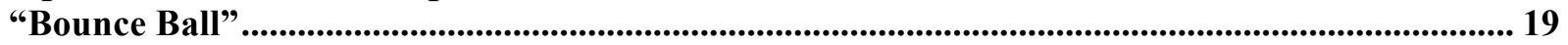

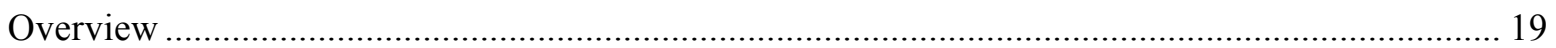

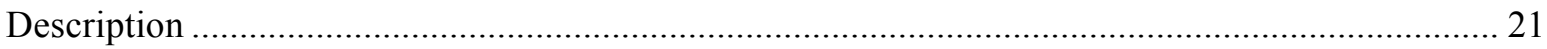

"Shimmy She Wobble" .......................................................................................................................................... 24

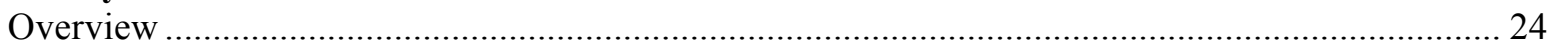

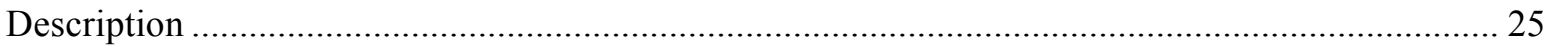

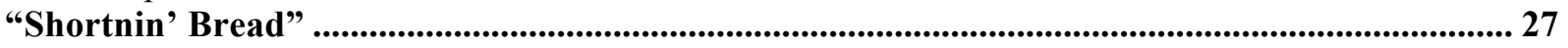

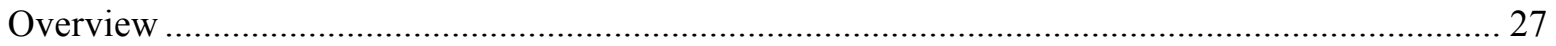

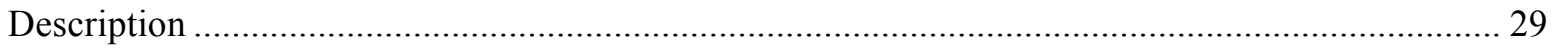

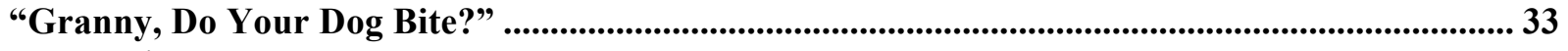

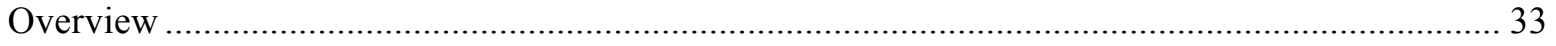

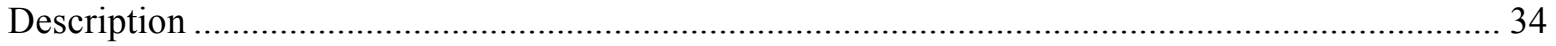

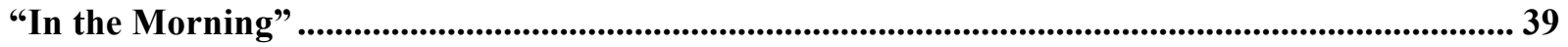

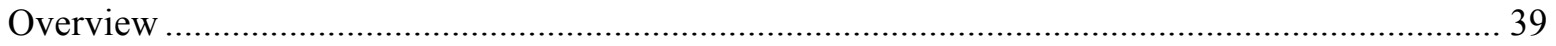

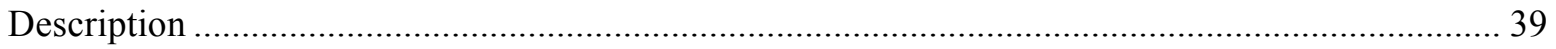

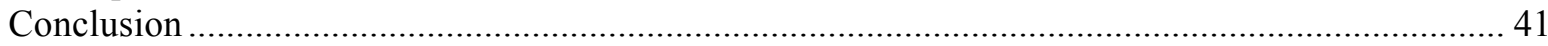

Chapter 4: Final Thoughts ............................................................................................................. 43

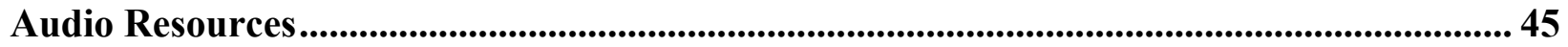

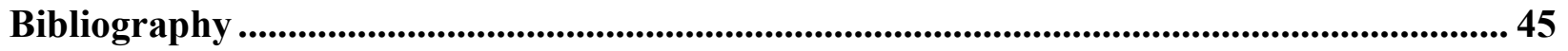




\section{List of Figures}

Figure 1.1 Heritage Model ............................................................................................ 6

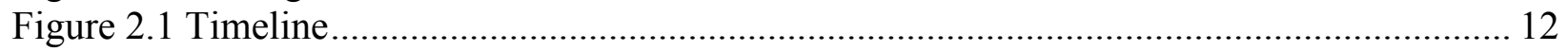

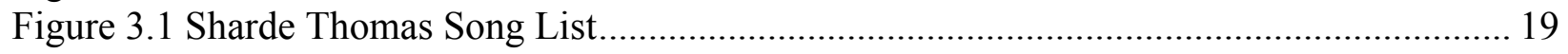

Figure 3.2 "Bounce Ball” Othar's Pitch Set ................................................................. 21

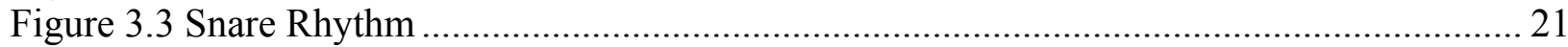

Figure 3.4 Bass Rhythm................................................................................................... 22

Figure 3.5 "Bounce Ball" Sharde's Pitch Set ........................................................................... 23

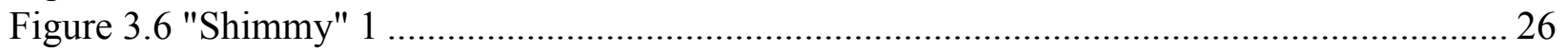

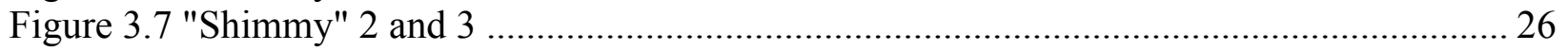

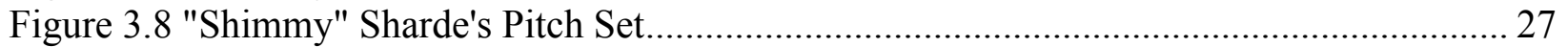

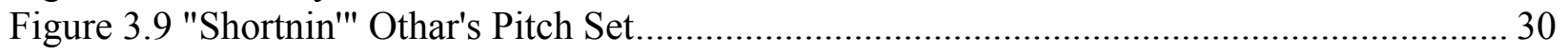

Figure 3.10 "Shortnin"" Sharde's Pitch Set.......................................................................... 30

Figure 3.11 Midi Bass/Hand-Clap Rhythm ................................................................ 31

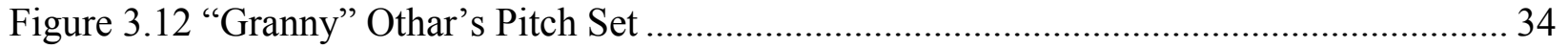

Figure 3.13 "Granny" Snare Rhythm ................................................................................. 35

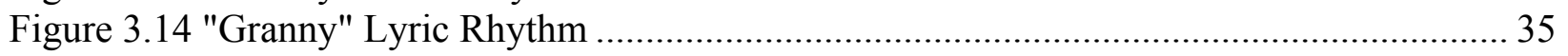

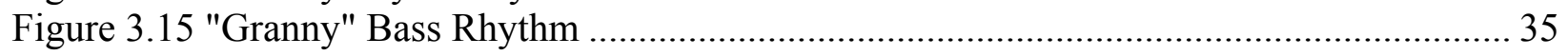

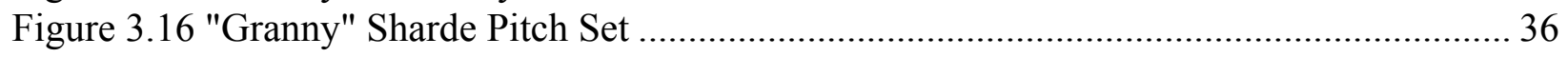

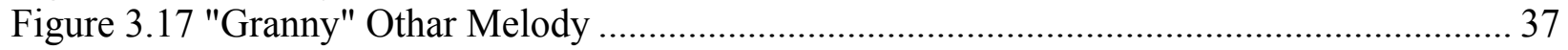

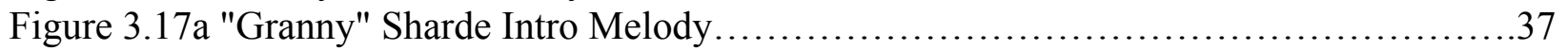

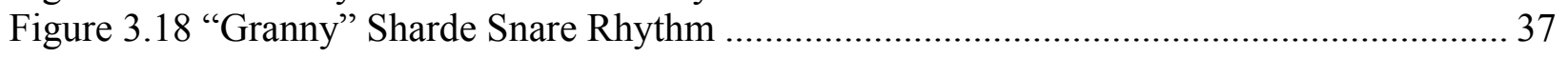

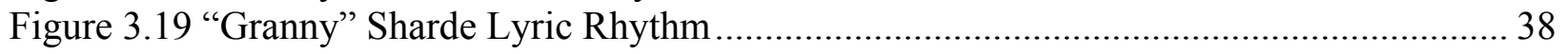




\section{Chapter 1}

\section{Introduction}

This thesis highlights the tradition of Fife and Drum Blues music of North Mississippi by looking deeply into the recordings of Othar Turner and his granddaughter, Sharde Thomas. In this thesis, the discussion of heritage and folklore studies will reveal how this music has changed over time. Sharde, sometimes referred to as Shardé, learned the traditions as a child and has now become a primary culture bearer of the tradition. Since Othar's passing, Sharde has performed in many venues around the world. Many of her performances include the traditional songs by her grandfather however Sharde introduces her own ideas within her musical performance. In her performances, Sharde uses a combination of musical techniques, instruments, and styles that are not found in Othar's music. With Sharde's interpretation and inspiration, along with her own compositions, the traditional Fife and Drum Blues genre is moving in new directions. This thesis examines how traditions are preserved, developed, and changed through generational interpretation and the influence of technology.

This research demonstrates how these traditions have adapted over two generations. As oral traditions were the primary form of maintaining tradition, Sharde has used technology, social media, and other formats to bring these traditions to larger audiences. Sharde uses her own creative development to present a new approach to the old traditions of her grandfather. This research provides interdisciplinary insight to these developments that could have the potential to impact many different areas of study. 


\section{Significance}

Many recordings were made of of Othar Turner's between the 1950s-1990s. However, the impact of his granddaughter, Sharde, is crucial with the current state of the tradition. Sharde is the current keeper of Othar Turner's traditions, but she is also implementing new music and reinterpreting the older styles. Although I have not grown up in the tradition myself, I connect with these developments as a white drummer and native of North Mississippi. These traditions are relative to me by geographic region, but may have been obscured by the racial dynamics of the region. I seek to show the importance of tradition, heritage, and innovation of music through the example of Sharde Thomas.

\section{Limitations}

The scope of this study looks at an album recording of Othar Turner's most popularized songs alongside two of Sharde Thomas's albums and music released on iTunes. Through this process, there will be several examples of Othar's iconic works and how Sharde has taken these works to create her own interpretation. In this comparison, Othar's representation and purpose is evaluated to that of Sharde's. This explains not just the musical differences but reveals how audience and technology play a role in the performance practice.

\section{Literature Review}

This thesis examines Othar Turner's latest album, Everybody Hollerin' Goat, as well as two albums of Sharde Thomas, What Do I Do? and Shawty Blues, all of which will be listed at the end of this document. Othar Turner's recordings provide the traditional representation of the Fife and Drum Blues music while Sharde Thomas's recordings demonstrate the developments and innovations that have taken place over time. An analysis of these recordings delivers the necessary information to determine the similarities and differences for a quality comparative 
study. Upon examining these recordings, they provide an accurate representation of the model of "Heritage" and how these differences and similarities circle around this idea.

Kathleen Danser's “Representations of African American Fife and Drum Music in North Mississippi” provides a quality historical background. Her work primarily explores the representations and interpretations of audio, video, and film recordings. Danser's primary focus is from the perspective of those who captured these recordings and its effect on the portrayal of these traditions. To build upon her work, I provide a new "representation." This thesis specifically examines the musical styles and traditions. Danser provides a great insight into media representations, however, looking more musically, I evaluate the differences between Othar's final recordings to Sharde's current recordings. Although much of her research and findings are used in this research project, this thesis looks at the performers specifically and how they have adapted and developed these musical traditions over time through heritage and folklore theories (Danser 2011).

One of the approaches that I will take with my research will be from Rodney Harrison's book Heritage: Critical Approaches. In this book, Harrison defines what heritage is along with how this concept is shaped through modernity, materiality, diversity, and sustainability. Harrison's approach is an interdisciplinary one. As an archeologist, Harrison approaches the idea of heritage from various angles. With this perspective, Harrison provides a broad lens to identify and define heritage and its use in today's society. I use Harrison's research as a model in this thesis to describe how Othar's traditions and Sharde's innovations all correlate around the idea of "Heritage" (Harrison 2013).

Living Folklore: An Introduction to the Study of People and Their Traditions by Martha Sims and Martine Stephens is a book that focuses on the study of folklore and how these apply to 
everyday life. This book breaks down formal and informal folklore studies and how these different approaches aim to appeal to a variety of audiences while still focusing on the traditions they are observing. This book breaks down the basic meaning of: "What is Folklore?" "What is a Folk Group?" "What is Tradition?" "What is Ritual?" "What is Performance?" By exploring these questions this book provides an understanding of interpreting folklore and discusses the fieldwork process for ethnographies. These studies directly correlate with Harrison's heritage model and offers an inside view of the creators of folklore. This book will guide my research to better understand and direct my model of heritage as explained by Harrison (Sims and Stephens 2011).

As one of the leading ethnomusicologists to document and study the music of African Americans in Mississippi, Alan Lomax's work as an ethnomusicologist is essential to this project. His book, The Land Where the Blues Began, is a memoir of his experiences in the Mississippi Delta during the 1930s and 1940s. In this book, he discusses interactions with several Mississippi blues artists and legends. One of these artists is Othar Turner. Although Lomax's appearance in the history of Mississippi Fife and Drum Blues is significant, this book will only be tangential to this particular study and will not be of primary use. His early recordings of Othar Turner will not be used as I examine his later works to focus on the transition between Othar Turner and Sharde Thomas (Lomax 1993).

There are many articles on the topic of African-American Folk Music that discuss a variety of musical traditions throughout the Southern United States. Many of these articles that I have found to have similar topical discussions were published through the American Folklore Society. Other items include books, encyclopedia entries, or journal articles that discuss AfricanAmerican Blues traditions, African-American folk studies, or a combination of both. Many of the 
Fife and Drum findings are included and explained in Kathleen Dansar's work mentioned above. These findings, while important, are only tangential to this study and will not be of primary use but are included in the bibliography.

\section{Methodology}

Through comparison of these recordings, I explain the transition between Othar's recordings to Sharde's current recordings. I then discuss the topics of Heritage and Living Folklore to describe how they are present in the preservation, development, and innovation of Sharde Thomas' music today. Through this process, I show how Sharde is able to have relevance with today's audience as well as maintain this theme of heritage. The model in Figure 1.1 below demonstrates this process. This model will act as a guide to show how these different areas interact and are connected around this idea of heritage. Although each circle surrounding heritage has its own characteristics, each one is connected and encapsulates the concept of heritage. 


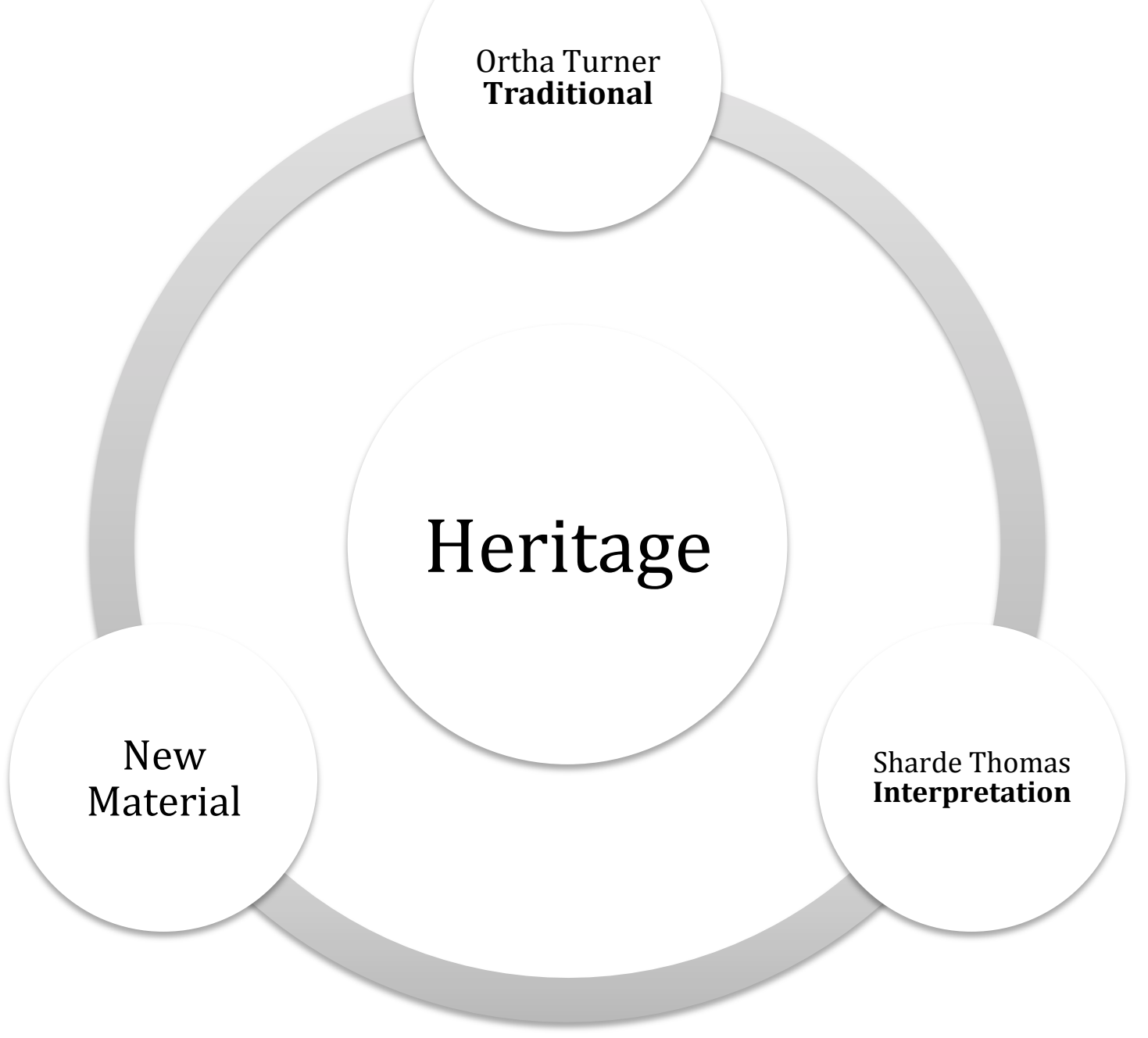

Figure 1.1 Heritage Model 


\section{Chapter 2}

\section{Heritage and its Application to the Music of Sharde Thomas}

This chapter will discuss and define what heritage is. It will also discuss how the use of technology, performance, and modernity apply to the music of Sharde Thomas. These factors explain how the music of Sharde has changed over time and explains the differences between her

and her grandfather Othar Turner. With the help of the music analysis from the previous chapter, and other scholars who discuss these topics, we can look deeply at how these components make and define the development and innovation of Sharde.

\section{Background}

Fife and Drum Blues music in the southern United States has a complex background. Traditional Fife and Drum music was used in the military as a form of signals during battle and other calls on military camps. Before the American Civil War, many Africans were displaced from their homeland and forced to work as slaves on many plantations across the Colonial United States. Particularly, the southern states had various groups of Africans mixed together. Kathleen Danser states that:

Little is known about early teaching methods of the instruments of black slave fifers and drummers. Eileen Southern, prominent scholar on the subject, suggests that slaves fashioned their own instruments based on the knowledge of instrument making from their motherland while Steven Cornelius suggests that plantation owners and the military purchased their instruments and provided instruction. One can only speculate about the kinds of instruments used, and how they were learned. It is plausible, given West African traditions of instrument making (e.g., drums from trees and animal hides and fifes from 
hollowed cane) and practices of orature (e.g., parables, storytelling, spoken-musical rhythms), that early fife and drums played by African slaves in the United States were hand-made and that learning occurred through routine and repetition on the battlefield or on the plantation (Danser 2011, pp. 27-28).

African American slaves were introduced to Fife and Drum through the means of the military. This is why some of the characteristics are similar with instrumentation (e.g., snare drums on a sling, bass drum, cane fifes). Danser goes on to say that: "During slavery, plantation life was an intimate intercultural space among and between Anglo and African Americans. It is likely that there was borrowing, blending, and adaptation of musical and dance styles. Black music production had qualities of formal and communal performance activities that incorporated dance as well as varied musical styles. It was common that black music production in Mississippi included celebration of holidays, end of harvest season, church services, sharing music with fellow slaves, and performing for 'the master' or plantation guests" (Danser 2011, p. 29).

There is little documentation on how these musical traditions continued after the Civil War. However, Danser states that, "Two pieces of information about the continuation of this musical practice include: (1) A Samuel Benjamin drawing, published in 1878 by Harper's New Monthly Magazine, depicting eight black children of various ages playing fifes, bass (box) and snare (box) drums as well as cymbals and bugles. (2) Mississippi fifers Sid Hemphill (Lomax 1993) and Othar Turner (Mitchell 1971), reported in fieldwork interviews that they received mentorship on the fife from neighbors and became part of the fife and drum bands as early as the 1920s" (Danser 2011, pp. 29-30).

These traditions continued and artists like Othar Turner became the leaders of holding these traditions. For this research, I specifically wanted to look at the end of Othar's musical 
career and compare that to Sharde as she is the new keeper of the tradition. Although there are many other blues musicians that certainly have influenced these traditions, I focus my research to that of Othar and the transition over to Sharde. This is where the comparative musical descriptions of this research come into play.

\section{Heritage}

Heritage is a concept that has been widely debated within the field of heritage and folklore. In Rodney Harrison's book, Heritage: Critical Approaches, he explains that heritage is a broad spectrum of things both tangible and intangible, ranging from museums and monuments to food and songs. He provides an extensive list as to what heritage could be. However, heritage requires people to define what these objects are. Harrison states, "It is perhaps helpful in the first instance to point out that heritage is not a 'thing' or a historical or political movement, but refers to a set of attitudes to, and relationships with, the past" (Harrison, 2013, p. 14). With this view, it is understood that society's relationship with heritage depends on the relationship it has with the past and the experience of the present.

This is particularly important for the case of Sharde Thomas. Her relationship and experience with her grandfather Othar is one that no one else could have experienced. However, through her music, Sharde explores this relationship and expresses it through her interpretation and experiences of today. Othar's experiences of learning the fife and performing were vastly different than the experiences that Sharde had and continues to have. In the liner notes for his Everybody Hollerin' Goat album, Othar tells the story of how he learned how to play the fife:

I was about sixteen years old (making it about 1923) when I started blowing the cane,"

Othar told Luther Dickinson, his firned and producer of this fine album. "It was an old man they called R. E. Williams, a tall slim man. We all come out of the field when it rain, 
too wet to pick cotton, and he be at his house blowin the fifes. I wasn't knowing what it was.I say say ‘Mr. R. E., how you make that? Will you make me one?' He say, 'Son, if you be a smart, industrious boy, listen to your mama and obey 'er, I'll make you a fife.' I wish it was tomorrow but was bout four weeks, he say, 'Here your fife.' I say, 'I sho do thank you.' He say, 'You ain't never gonna do nothin wit it.' I say, 'But I try.' He say, 'Well son, don't nothing make a failin but a tryin.' Everywhere I get a chance, I be tryin to blow that cane. Mama say, 'Put that dadblamed cane down, I is tired of it.' Mr. R. E., he turned round blowin the cane and I just stood there watchin him. And I learned how to blow it. I made m'own songs (Turner 2001).

As this story continues, it is clear that a legend was born. Othar continued learning and playing, taking opportunities from R. E. and his friends to learn how to play the drums as well. His fascination continued, which spread to his children. He tells the story of how he was exposed to the drum:

Then there be a man called Will Edwards, he owned some drums. One day, we heard 'em, we say, 'Mama, I hear some drums.' She say, 'Y'all do your work, get ever'thing done so we come home tonight, I give y'all a bath an' carry you up there.' We say, 'Yes ma'am, yes ma'am.' We do our work, she give us a bath, and we go up there. There's people standin round, old men down there playin drums, puttin drums between their legs. They say, 'What you lookin at, son? Gettin down ain’t it. You wanna try it?' I say, 'Yessuh.' He say, 'Boy, don’t bust my drum.' I say, 'Nosuh.' I got that drum, mess around, be playin all round it. He say, 'Listen at him, Will, listen at him, that boy yonder playin that damn drum.' Then, after a while he say, 'Awright young man, you be rarin for this, you got a job, you one of my players.' And I started playin with other peoples. Guys 
found I could play the cane, they be hirin me, carryin me to different places. Then I say, 'I'm gonna buy me some drums and start givin picnics.' My kids say, 'Daddy, you gonna do that? You got nobody to play.' I say, 'I'm gonna hire somebody to play.' So I did, and my daughters, they kept a watchin me and came back, and ask my wife, 'Who's that messin with my drums?' She say, 'That's your chillen.' I say, 'My chillen? You mean to tell me my chillen be messin with my drums? Y'all go get the drums and bring it out. I wanna see can you play.' They got them drums and they play them drums. I say, 'Well hooray for y'all!' (Turner 2001).

This began a family tradition. Othar and the Turner family began hosting picnics and celebrations regularly for friends and family to participate. Sharde grew up in these picnics and traditions and was noticed at an early age. Writer Robert Gordon offers some insight into this relationship:

Othar is ninety years old and powerful. His friends call him "Gabe," like the archangel who blows the horn. His daughter Bernice has been playing since she was a child; her teenaged sons Andre and Rodney and her nephew Aubrey (everyone calls him Bill), they all blow the fife and beat the drums. But when it comes to family fife blowing, no one blows like Sharde, who is eight and has been blowing the fife since she was five. She's so young, it's hard to imagine she knows what she's doing. But she stands firm-footed like her granddad, holds the fife with authority, and blows "Shimmy She Wobble," which also happens to be the first song Othar learned (Gordon in Turner 2001).

Othar made true to his promise of starting picnics. Even after his passing, the annual Goat Picnic still takes place after nearly sixty years. There are many other festivals and gatherings that have occurred, like the North Mississippi Hill Country Picnic, but the annual Goat Picnic is the 
one that highlights the life of Othar Turner the most. Sharde and the Rising Stars Fife and Drum Band still participate and lead the celebration. Figure 2.1 displays the significant events throughout the lives of Othar and Sharde that are discussed in this thesis.

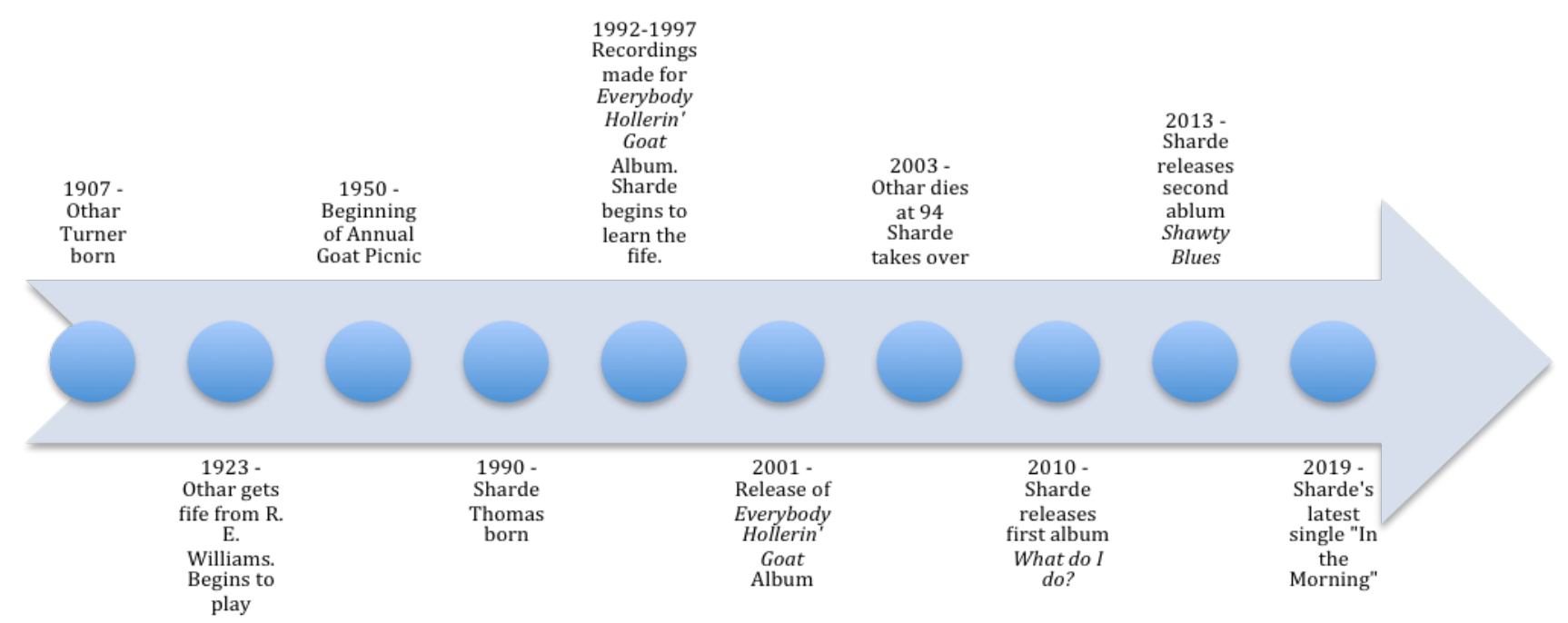

Figure 2.1 Timeline

By the time Sharde came around, Othar was well-established in his music. Sharde's talent, interest, and poise were noticed at an early age. Because of this, Sharde became the obvious up-and-comer to the traditions of her grandfather. A new generation began sprouting up. Although the songs were the same, the times of the 1990s were much different than when Othar learned and was exposed to the music in the 1920s. Because of this, Sharde's influences are different than Othar's (Rawls 2019, myspiltmilk.com).

As the keeper of the traditions, Othar's interpretations were widely deemed to be the most prevalent, but, after his passing, Sharde's own musical interpretation took shape. After seventeen years, we can see how Sharde's leadership has taken the music to new horizons. She 
has performed for a variety of festivals and concerts across the United States and even

Switzerland. Many of her musical decisions have shaped the direction of her music that has been noticed by many fans across the globe (Chicago Reader 2018). This brings the discussion to the topic of "modernity."

\section{Modernity}

Harrison discusses modernity and explains its relationship to heritage, noting that "The experience of modernity is thus one of novelty, progress, speed and rupture from the traditions of the past" (Harrison 2013, p. 24). He goes on to say, "If one of the most distinctive aspects of modernity is its emphasis on linear progress and the distinct break it perceives between past and present, it follows that it must 'manage' its relationship with the past carefully" (Harrison 2013, p. 25). This is especially true in the case of Sharde. She still performs the songs of her grandfather, as well as continues to play on his fife, however, her incorporation of technology and a variety of instruments, she recreates these songs and brings them to a modern view. This is not to say that these reinterpretations are "better" than her grandfather. This simply explains how Sharde's reinterpretations are maintaining the traditions of Othar. Harrison suggests that although changes are made to the traditions, the traditions still remain intact. He notes that “...the 'time' of modernity is not straightforward, as it involves a complex doubling in which it defines itself simultaneously as both 'contemporary' and 'new." He explains this further by suggesting that, "In other words, modernity creates for itself a past that is perceived to be both immanent (contained within) and imminent (impending) in the present" (Harrison 2013, p. 25).

This concept lines up with Sharde's latest single, "In the Morning." She uses electronic sounds, effects, and a technology that is popular in today's recording, however her relationship to her heritage is still present with the use of the "Shimmy She Wobble" melody at the end of her 
song. Thus, "In the Morning," is a great example of modernity within Sharde's music. Another way to examine this is through performance.

\section{Performance}

When discussing the concept of performance and its relation to heritage, I have included the scholarly work of Martha Sims and Martine Stephens, the authors of Living Folklore: An Introduction to the Study of People and Their Traditions. In chapter five of this book, the authors focus on the topic of performance, noting that "Performance is an expressive activity that requires participation, heightens our enjoyment of an experience, and invites response" (Sims and Stephens 2011, p. 131): This statement fits well with Harrison's notion that heritage relies on the relationships between people and tradition. They explain further that, "In order for a performance to happen, a recognized setting must exist (participants have to know a performance is taking place) and participants (performers and audience) must be present" (Sims and Stephens 2011, p. 131). This relates well to the picnics and relationships between Othar and his family, neighbors, and friends.

In Kathleen Dansar's research on Othar, she explains in detail her experience of that Turner Family Picnic. Her descriptions provide a great insight into their performance. The interactions between the performers and the audience were evident. In her recollection of attending the Turner Family Picnic, she describes the performance of Sharde and the Rising Stars Fife and Drum Band. She explains that the band made a procession into the picnic making a grand entrance. She states: "The procession began at the main entrance gate of the site welcoming event participants to the event. Sharde, facing the drummers who were in close proximity to her, played a few bars of the melody of the song, 'Glory, Glory Hallelujah,' which seemed to signal the drummers both the specific song and its tempo. The snare drummers joined 
her in the performance before the bass drum added the low-end tones a few bars later" (Danser 2011, p. 17). This information supports the musical description found in chapter three. The sequence of entrances between the instruments from the analysis is consistent with this performance Danser witnessed in 2010. It is also interesting to notice that, even though "Glory, Glory Hallelujah" was not recorded on either of Sharde's albums, the song is found on Othar's Everybody Hollerin' Goat album. This further shows Sharde performing the songs of her grandfather in another account.

Danser goes on to quote Bobbi Turner, a member of the Turner family, who suggests that "Sharde can do what she want being all creative and such but she still have to play the old stuff for us. That's the tradition and we make sure she do that for us" (Danser 2011, p. 17). This quote supports how these relationships of traditions occur and how those closely related to these traditions are given space to move within it. Sharde is able to "be creative," in Bobbi Turner's words, because of these relationships between those who hold these traditions valuable. Sharde is able to incorporate new musical styles, instruments, effects, recordings, etc., is through the trust built between her family and those who admire the traditions of her grandfather Othar. She does not dismiss those traditions, as explained earlier through the analysis. However, how these changes are made can be further explained by Sims and Stephens, who observe that "The details of the setting and relationships between participants can be quite complex and fluid, but all participants understand that they are engaged in some kind of performance activity" (Sims and Stephens 2011, p. 131). As seen in the description in chapter three, Sharde expands the audience of these traditions by incorporating new musical ideas. Sharde is able to creatively maintain the traditions as she still participates in the performances like her grandfather. However, she draws a larger audience by the use of technology, social media, and through her reinterpretations of these 
traditional songs and originals she creates. These factors were not familiar during Othar's time. However, Sharde is still able to communicate within the community of these traditions while still expanding on her ideas.

Sharde's musical performance has her own merit, however, because of her relationship to Othar, this provides her space to create music freely. She not only performs the musical traditions of her grandfather, but she also expresses her own musical interests as well. This incorporates a platform for a broader audience. The influence of hip-hop can be seen in her musical performance as hip-hop allows a space to tell narratives and emphasize a locational identity. In the book, Let the world listen right: the Mississippi Delta hip-hop story by Ali Neff and William Ferris, they explain how hip-hop has influenced the blues music of Mississippi. They state, "Although black residents of the Deep South are geographically removed from the East Coast urban situation, the early hip-hop movement was not lost on them. Just as the Delta bluesmen once incorporated national jazz and pop styles into their performances, young practitioners in the Delta introduced elements of New York hip-hop into their traditional local rap styles as soon as it hit the airwaves. In one form or another, rap has been a prime discursive and performative tool throughout the history of the Deep South" (Neff and Ferris 2009, p. 139).

Sims and Stephens also note that "Each of us interprets the performances of people in our own folk groups naturally as part of our group's communication process. If group members and audiences are not able to understand and interpret someone's performance, it may not be a successful expression of breaking down the elements of a performer's ideas" (Sims and Stephens 2011, pp. 131-132). Upon examining the music and performance practice of Sharde, it is clear that her communication within the community that holds these traditions is strong. She is able to 
continue playing Othar's music, reinterpreting it and incorporating her own musical ideas that still sustain the heritage found within the performance.

\section{Conclusion}

Sharde's contemporary interpretations of Fife and Drum Blues music pushes the music into a new direction but still contains traits of her grandfather Othar Turner's music. By adding new instruments and the use of technology, Sharde develops and creates an innovative approach to create this musical style. She preserves this music by continuing to perform these songs, however she incorporates her ideas to re-contextualize them for a newer audience. Therefore, modernity has shaped how this music is performed and created in today's setting. 


\section{Chapter 3}

\section{Musical Description of Othar Turner and Sharde Thomas}

For this musical description, I have chosen four songs from Othar Turner's Everybody Hollerin' Goat album that his granddaughter, Sharde Thomas, also has interpreted on her What Do I Do? and Shawty Blues albums. These songs are "Shimmie She Wobble," "Bounce Ball," "Short'nin' Bread," and "Granny Do Your Dog Bite?" "Shimmie She Wobble” and "Bounce Ball" can be found on Sharde's first album What Do I Do? The other two, "Short'nin' Bread" and "Granny Do Your Dog Bite?" are found on her second album Shawty Blues.

This analysis shows the transition of musical ideas from Othar to Sharde. In Sharde's What Do I Do? album notes, she states:

My name is Sharde Thomas. I am the granddaughter of Mr. Othar Turner. I started playin music at the age of 7 and I knew it was something I wanted to do. Started writing my own songs when I turned 13 years old. That is something I enjoy doing too. Seven years later I released my 1st album called "What Do I Do". This album is dedicated to the late Othar Turner and Bernice Turner. Once you listen to this album you will laugh, think about your life, and shed a few tears. I enjoyed writing and singing on this album and I hope you enjoy listening to it (Thomas 2010).

It's interesting to notice that at the same time her grandfather released his last album, Sharde was learning to play the fife. Unfortunately, the amount of time that is shared between Othar and Sharde in their musical timeline only lasts approximately six years.

Even though Sharde did not release her own album until after Othar died, it is clear in her music that she continues the traditions of her grandfather. These claims can be found in the comparative description, which considers how Sharde's interpretations have progressed up to her 
latest single, which was released in 2019. This chapter will demonstrate how Sharde incorporates the traditional musical styles of her grandfather into her own interpretations, and how her style has changed over time.

In regards to Sharde's recordings, Figure 3.1 shows the name of the song, the album in which the song was released on, the year it was released, the track number on the album, the length of the track (in relation to Othar's recordings), the tempo (in relation to Othar's recordings), the instrumentation (if different than Othar's), and any other important information needed for that track.

Othar's Songs played by Sharde

\begin{tabular}{|c|c|c|c|c|c|c|}
\hline Title & Album & $\begin{array}{c}\text { Track } \\
\text { Number }\end{array}$ & $\begin{array}{c}\text { Track } \\
\text { Length }\end{array}$ & Tempo & Instrumentation & Other \\
\hline $\begin{array}{c}\text { Bounce } \\
\text { Ball }\end{array}$ & $\begin{array}{c}\text { What } \\
\text { Do I } \\
\text { Do? } \\
(2010)\end{array}$ & 9 & $\begin{array}{c}2: 53 \\
(\text { longer) }\end{array}$ & Slower & $\begin{array}{c}\text { Cymbals/Drum } \\
\text { set added }\end{array}$ & \\
\hline $\begin{array}{c}\text { Shimmy } \\
\text { She } \\
\text { Wobble }\end{array}$ & $\begin{array}{c}\text { What } \\
\text { Do I } \\
\text { Do? } \\
(2010)\end{array}$ & 12 & $\begin{array}{c}3: 17 \\
\text { (shorter) }\end{array}$ & Similar & Similar & Recorded live \\
\hline $\begin{array}{c}\text { Short'nin' } \\
\text { Shawty } \\
\text { Blues } \\
(2013)\end{array}$ & 6 & $\begin{array}{c}3: 19 \\
(\text { longer })\end{array}$ & Similar & $\begin{array}{c}\text { Sampled Bass } \\
\text { Drum instead }\end{array}$ & $\begin{array}{c}\text { Overdubbing/Half- } \\
\text { time feel }\end{array}$ \\
\hline $\begin{array}{c}\text { Granny do } \\
\text { your dog } \\
\text { bite? }\end{array}$ & $\begin{array}{c}\text { Shawty } \\
\text { Blues } \\
(2013)\end{array}$ & 8 & $\begin{array}{c}3: 12 \\
\text { (longer) }\end{array}$ & Slower & $\begin{array}{c}\text { Synth Bass/Drum } \\
\text { set added }\end{array}$ & Overdubbing \\
\hline \multicolumn{7}{|c|}{} \\
\hline
\end{tabular}

\section{"Bounce Ball"}

\section{Overview}

This song is the second track on Othar's Everybody Hollerin' Goat album and track number nine on Sharde's What Do I Do? album. Othar's version is two minutes and twelve seconds (2:12) while the track on Sharde's album is two minutes and fifty-three seconds (2:53). Part of the reason for the longer track on Sharde's album is due to her playing the song slower 
than Othar. The instrumentation for Othar's performance seems be two snare drum players, one bass drum player, and then the fifer. This is pictured as the album cover for Othar's Everybody Hollerin' Goat album (Turner 2001). However, Sharde's version also has a heavy emphasis on bass drums and what seems to sound like toms from a drum set. Sharde's version also has cymbals, which cannot be heard on Othar's version. With the heavier emphasis on drums and the use of cymbals, which sounds like Sharde added a drum set player to this recording to add a thicker texture to the rhythm.

Sharde's fife playing is also different than Othar's in that her tones are clearer and her notes are held out much longer than those on her grandfather's recording. This could either be a musical choice, or it could be attributed to the fact that Othar was nearly 90 years old and possibly could not produce as much air for longer notes. Regardless, Sharde's breath support allows her to play her notes longer at her slower tempo.

There are some similarities between the two recordings. Both versions start at a slower tempo than where they finish. Each start with just the fife and the drums come in after a few notes to set the groove. Gradually, the song speeds up and settles at faster tempo and remains that way until the end. Although there are more drums and the use of cymbals in Sharde's version, the outlining rhythm found in the snare drums are the same in both versions. I explain the tempos and instrumentation further in the analysis.

One difference that can be determined by these recordings is that Sharde's version seems to be recorded either in a studio or a closed setting. Othar's recording, which is not unfamiliar, seems to be played outside as you can hear the voices of children and others moving about casually in the background, mostly likely on Othar's farm in Tate County Mississippi (Danser 2011, p. 56). 


\section{Description}

In Othar's version, this piece uses five notes in its core melody. The range for this piece is a major $6^{\text {th }}$ and, on the fife, is played between D6 and B6 (Figure 3.2).

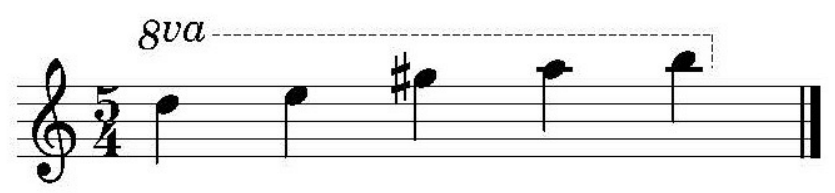

Figure 3.2 "Bounce Ball" Othar's Pitch Set

Before the song starts, Othar plays a loud, quick glissando from G\#6 to B6. With a brief pause, He begins to play the melody descending from B6, and outlines the E major triad going from B6 to G\#6 and down to E6. Establishing a rhythm with the melody, and after a four-count pulse, the snare drums enter on their pattern (Figure 3.3).

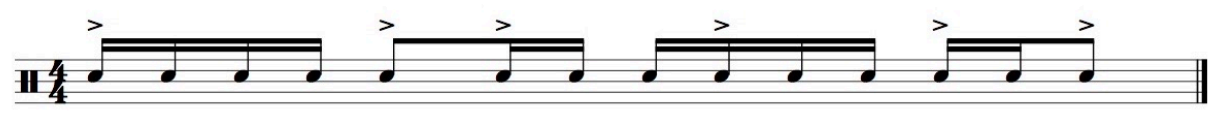

Figure 3.3 Snare Rhythm

This rhythmic ostinato remains static throughout the entire piece with very little variation.

After four counts of the snare drummers' entrance, the bass drum enters. However, before they lock in to their rhythmic pattern, they mark the downbeat of count one for two measures, emphasizing the beginning of the snare drum ostinato. After doing so, the bass drum begins playing its rhythmic ostinato. Their pattern outlines the snare drum rhythm (Figure 3.4). 


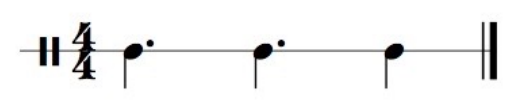

Figure 3.4 Bass Rhythm

This rhythm is the basic pattern heard throughout the entire piece and is mostly static. However, there are a couple variations to this this rhythm that emphasis other accented notes from the snare drum rhythm. Although more notes are sometimes added, the outlining rhythm remains the same. Some variations of the outlining bass drum rhythm can be seen in Figures 3.4a and $3.4 \mathrm{~b}$.

Var. 1

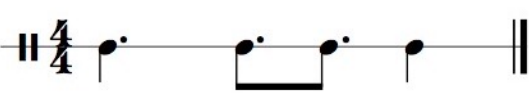

Figure 3.4a Variation 1
Var. 2

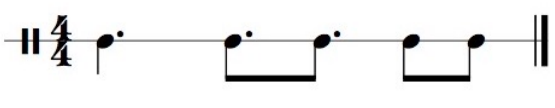

Figure $3.4 b$ Variation 2

Othar ends "Bounce Ball" by ending on the pitch D7. This is an interesting decision seeing as Othar did not play a note higher than a B6 throughout the piece.

Sharde's regularly uses six pitches in her performance of "Bounce Ball." The sixth note is an octave jump to the lowest note in the song. She also plays the tune in a different key. The note range for this song is still only a major $6^{\text {th }}$ like in Othar's version, with the exception of the 
added octave. However, Sharde's range is slightly lower starting at the pitch C6, as shown in Figure 3.5.

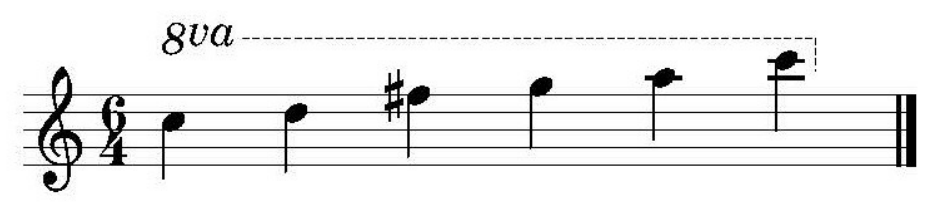

Figure 3.5 "Bounce Ball" Sharde's Pitch Set

The structure of Sharde's version is similar to Othar's, but her interpretation is much more fluid and legato. The beginning starts with just the fife. Immediately, Sharde sets the pulse. After about three counts, the snare drum sneaks in and plays the same pattern from Othar's version in Figure 2.3. This time, however, the bass drum enters after only one measure of the snare pattern with hits on the downbeat of count one. In Othar's version, the bass drum did this for two measures before starting their pattern. In Sharde's version, the bass drum hit on the downbeat of count one for four measures before starting their pattern. The bass drummer in Sharde's version also used more rhythmic variation than in Othar's version.

This slower tempo, the prolonged entry of drum patterns, and more legato style shows that Sharde made a musical choice to change the way Othar's version sounded. The added use of a drum set player and the effect of cymbals also help to emphasize a heavier groove. This emphasizes the slower tempo by using a rock style groove, which creates more space between the notes unlike the snare and bass drum parts. Although both versions are easily recognized as the same tune, the clear changes in key, articulation, tempo, and instrumentation mark a significant enough difference to indicate Sharde's musical interpretation compared to Othar's. 


\section{"Shimmy She Wobble"}

\section{Overview}

This song on Sharde's What Do I Do? album is recorded live and is labeled "Shimmie," with an "i" and "e" spelling as opposed to Othar's "Shimmy." This spelling is only seen on her album title. This track is three minutes and seventeen seconds (3:17) long. This is the only song recorded live on the album and not in a studio setting. At the beginning of the track, Sharde is heard saying to the crowd, 'Now we're gonna' bring you 'Shimmie,' one of my Grandaddy's favorites, Othar Turner. Give it up for Othar Turner! Y'all make some noise!” Instantly, the crowd responds with cheers. The interaction between Sharde and the audience happens again later in the tune. Toward the end of the song, while the drummers continue to play, Sharde talks to the crowd again, saying, "Y'all make some noise for Mister Othar Turner, y'all!" The crowd cheers again, and she plays the main melody of tune one more time before ending.

On Othar's album, "Shimmy She Wobble" or "Shimmie," is found three different times out of fifteen tracks, with each of these tracks significantly longer than Sharde's version on her album. The first take on "Shimmy" is $4: 18$, the second is $6: 30$, and the last is $9: 40$. This shows Othar's musical decisions and how he adds variety to way he plays his songs. It is fair to say that Sharde was correct when she said this was "one of my Grandaddy's favorites," as no other song is featured this much nor is any other song longer than the 9:40 version.

Each recording of "Shimmy" on Othar's album was made outdoors. The second and third recordings have stronger drum presence, and the fife sounds farther away, making it harder to hear. In Sharde's version, the fife is much more prominent. In contrast to "Bounce Ball," Othar's tones are fuller and the notes are held longer. This distinction could indicate a specific playing style or interpretation as Sharde performs her version similarly to her Grandfather. 


\section{Description}

As stated earlier, Othar has three different tracks of "Shimmy She Wobble" on his Everybody Hollerin' Goat album. I will call the first recording (track 1) "Shimmy 1," the second recording (track 5) will be "Shimmy 2," and the last recording (track 15) will be "Shimmy 3." Each version of Othar's recordings is important to analyze because they shows how he was able to play the same song three different ways.

All three versions start similarly with Othar playing the fife freely without an established pulse. After a short cadenza-like passage, the snare drum sneaks in with a rhythmic pattern that establishes a pulse and the tempo for the song. In the same way that the drums entered in "Bounce Ball," the drums layer in all three versions, starting with the snare, and then with the bass outlining the snare drum's rhythmic pattern.

One of the differences between the three versions can be heard in the drum entrance. Although they all wait and allow Othar to play freely, each time the snare drum enters at a different time in the recording. In Shimmy 1, from the time the recording starts, the snare does not enter until about 27 seconds. In Shimmy 2, the snare drum enters at around 0:20 seconds. In Shimmy 3, the snare enters at around 0:14 seconds. This is interesting as the delayed entrance of the drums are opposite of the length of the tracks. Shimmy 1 is the shortest recording of the song but has the longest wait for the drums to enter. Shimmy 3 is the longest recording and has the shortest delay of the drums' entrance. These prolonged entrances feature Othar's impromptu fife playing skills with each version of Shimmy showcases different musical variations and musical interpretations of Othar.

Shimmy 2 is in the middle when it comes to length of recording and delay of drum entrance, and this version has its own unique interpretation. When the snare drum enters in 
Shimmy 1 and 3, the tempo is immediately established and remains the same throughout the rest of the song. Both versions play the song at around 118-120 bpm. However, Shimmy 2 starts at around $100 \mathrm{bpm}$ with the snare's entrance. Unlike Shimmy 1 and 3, the tempo established with the snare's entrance does not stay the same throughout the song. The drums gradually increase tempo over the course of approximately 90 seconds. This accelerando is very slow, however; the 118-120 bpm tempo in Shimmy 1 and 3 are finally found in Shimmy 2 at around 1:50. Once the tempo reaches the familiar tempo of the other versions, it then remains the same for the rest of the song like the others.

The drum patterns played in "Shimmy She Wobble" are the same as in "Bounce Ball." There are very few differences in their parts and roles. The melody in this song is in a similar range from "Bounce Ball" with a couple of note changes. Shimmy 1 is in a different key than the others. However, there are only four primary notes used in the melody. In Shimmy 1, the notes range from D6 to A6. In Shimmy 2 and 3, the notes range from E6 to B6. The same intervals are applied, however Shimmy 2 and 3 are a whole step higher than Shimmy 1. The note ranges are found below in Figure 3.6 and 3.7. It is possible that Othar could have played on a different fife as there has been some findings of Sharde playing on different fifes as well (Centrum 2018).

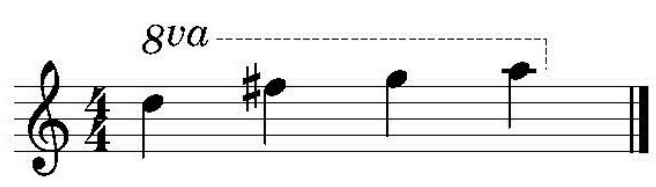

Figure 3.6 "Shimmy" 1

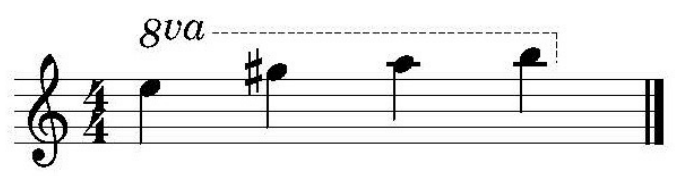

Figure 3.7 "Shimmy" 2 and 3 
In Sharde's recording, after her introduction of the song, she plays a few notes freely in Othar's style at 0:13 seconds into the recording. However, her musical choices are different using different notes and rhythms. The drums enter much sooner than in Othar's recordings, as she only plays for about five seconds before the snare drum enters and establish tempo. The tempo remains constant for the whole song but is slower overall than Othar's versions, maintaining between 105 and 107bpm. Her pitch choices are also different than Othar's. It is closer to that of Shimmy 1 of Othar's, but she adds the pitch C6 and G\#6 in the mix to expand on the melody (Figure 3.8).

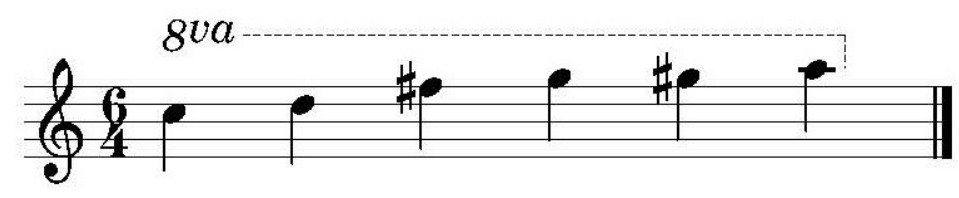

Figure 3.8 "Shimmy" Sharde's Pitch Set

Here again, we see Sharde expanding on Othar's recordings and interpreting things a little differently. Not only does she change the tempo but with the notes as well. She keeps the melody very clear and the drummers maintain the same rhythmic patterns and structure, however, she moves the melody differently and interacts with the notes in her own style.

\section{"Shortnin' Bread"}

\section{Overview}

The third track of Othar's Everybody Hollerin' Goat album, "Shortnin' Bread," is labelled as "Short'Nin/Henduck" and appears as the last track on Sharde's Shawty Blues album as "Shortnin' Bread." This song is a popular folk tune in the US South (Wade 2012, pp. 92-93). A variety of artists have also recorded versions of the song like the Andrews Sisters (Decca Records 1938) and The Beach Boys (CBS Records 1979). Othar's version is 2:49, and Sharde's 
version is longer, coming in at 3:19. However, the end of the song happens at 2:54 with approximately twenty-four seconds of silence left on the track.

Othar starts this song like the other recordings analyzed so far. He plays a few notes of the tune freely before the drums enter soon after. In this recording, the fife and the drums are heard and mixed much clearer. It is still outdoors as the voices of others are heard outside with children playing in the background. However, this recording is first time on the album that we hear Othar sing part of the song. After playing the melody on the fife a few times, approximately halfway through the recording (1:18), Othar begins to sing the lyrics to the tune. He sings the chorus of "Shortnin' Bread" twice: "Bring me the Skillet, Bring me the lid. / Mama's gonna cook some Shortnin' Bread. / Mama's gonna cook some Shortnin' Bread.” Then from 1:52 to 2:04, he sings some lines from different verses of another folk tune known as "Henduck" or the "Crawdad Song." Although it is difficult to hear some of the words he sings in the "Henduck" song, the first line he sings is heard clearly: "What did the hen duck say to the drake?" After he sings this, it is difficult to understand what lyrics of the song he sings next. There is another line of the song that seems to fit best has you can hear the words "lake," "bank," and "dry" clearly. With that, it seems that he sings another line from a different verse of the song: "Whatcha gonna do when the lake runs dry? / Sit on the bank, and watch the crawdads die." However, Othar omits the main chorus "Henduck," the most popular part of the song that discusses fishing for crawdads. Nonetheless, it seems to fit perfectly with the song "Shortnin' Bread," as both are songs about cooking. After he sings part of the "Henduck" song, he returns to the fife to play the "Shortnin' Bread" melody again three times before ending this piece.

In Sharde's Shawty Blues album, she explores more with her musical choices than she did in her previous album What Do I Do? She does not include the "Henduck," and she also uses a 
recording technique called "multitracking" or "overdubbing" as part of her recording. Overdubbing is a common recording practice in which the primary tracks are recorded and then replayed while the musicians record another track on top of it. Although these practices have been used for years, in Othar's time, these techniques would likely have required more expensive equipment and time in a studio rather than the field recording-type setting used in Othar's Everybody Hollerin' Goat album. However, Sharde uses this recording technique to sing harmonies with herself as well as the fife mixed on top of her singing. At the beginning of the song she even sings "This is the remix" before she starts singing the words to "Shortnin' Bread." This idea of a "remix" is common in today's DJ culture and seems to be a crucial part of Sharde's musical production (Neff and Farris 2011).

The drums play a different role in this recording as well. Instead of a fife entrance followed by a drum entrance, the beginning of this tune uses a combination of MIDI bass and handclap sounds to indicate a pulse first before you hear any other instruments at all. Once the pulse is established, Sharde does not start with the fife, instead she sings the "Shortnin' Bread" melody. When the drums enter, they also do not stay for the remainder of the song like in Othar's recordings. The drums play for a few phrases and then stop, and then enter again later. The MIDI bass and handclap sounds however are present throughout the entire song. This indicates that Sharde further used studio technologies and are different than what Othar would have used.

\section{Description}

In Othar's version, we hear a similar start like the other songs analyzed. Othar plays a couple notes of the melody freely. The snare drum quickly enters at 0:04 playing the Figure 3.3 rhythm. The bass drum enters marking the downbeat of count one like in "Bounce Ball," and 
then outlines the rhythm like in Figures 3.4, 3.4a, and 3.4b. Once they enter, they maintain their rhythmic patterns for the duration of the song. The tempo for this song stays at about $120 \mathrm{bpm}$. Othar plays five notes in this melody that span across an octave of $\mathrm{C \# 6}$ to $\mathrm{C \# 7}$ (Figure 3.9).

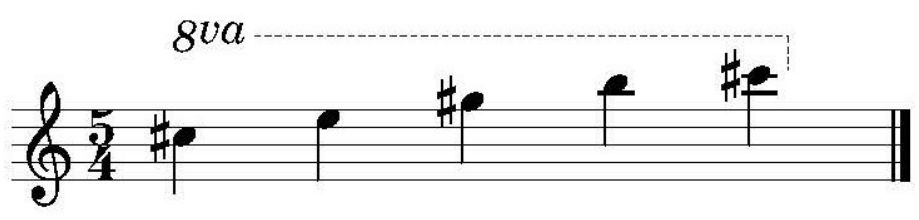

Figure 3.9 "Shortnin"' Othar's Pitch Set

At 1:28, Othar sings the melody of the song "Shortnin' Bread" while the drums continue to play. He sings these lines twice and then sings the lines from "Henduck" once. At 2:04, he plays the fife and again and continues for the rest of the song.

Sharde's version uses more notes and a slightly slower tempo, and the drum parts are slightly modified with a different role. Sharde plays her version on the fife a whole step down, that covers a range of B6 to C6. This could be because of a different fife. She also incorporates more notes in her version. She uses seven notes to Othar's five. However, the note $\mathrm{C}$ that she uses is only found in her fife introduction at 0:27. She does not use this note for the core melody and is not heard on the fife after that.

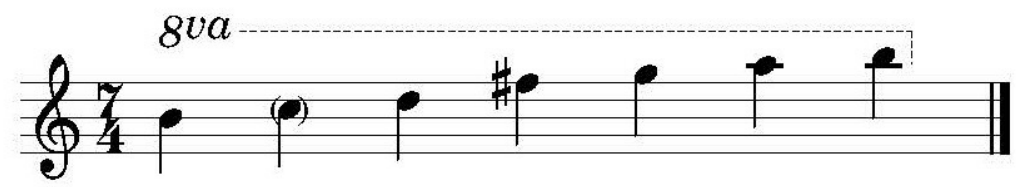

Figure 3.10 "Shortnin'" Sharde's Pitch Set

As stated earlier, Sharde incorporates a MIDI bass and handclap sound that plays from the very beginning of the track until the end. This rhythmic pattern gives a sense of a half-time 
feel rather than a steady walking tempo that has been found in the drum parts as seen in Figure 2.3 and 2.4. Instead, the hand-clap sound is heard on count 3. The tempo in Sharde's version is only slightly slower, settling around 114-116 bpm. However, this half-time feel gives the piece a new feel. Musically, this changes how the overall beat is interpreted. This provides another musical element to the song giving a sense of slowing down without changing tempo. This rhythmic pattern is seen below in Figure 3.11.

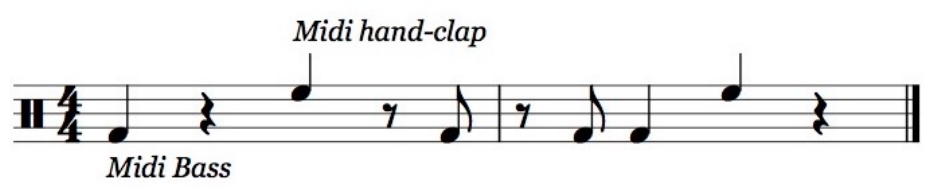

Figure 3.11 Midi Bass/Hand-Clap Rhythm

This pattern remains constant throughout the piece, however, there is one variation that is heard on count 4 of the second measure of the phrase that emphasizes more of this "half-time" feel (Figure 3.11a).

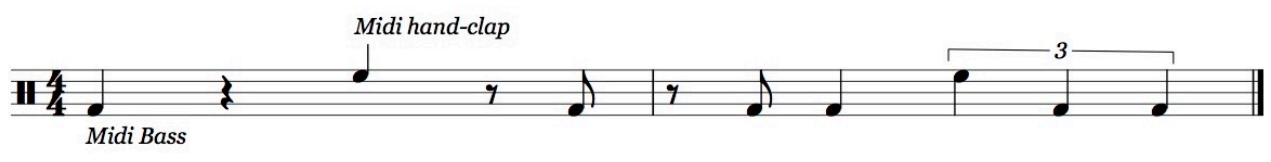

Figure 3.11a MIDI Bass/Hand-Clap Rhythm Variation

Right away, we hear this pattern of "bass and snare" with the MIDI sounds, but it is not heard on acoustic instruments and is not the familiar rhythmic pattern that is heard in Othar's version. With this, she sings "This is the remix," indicating that she is performing her own creative interpretation of the song. This use of electronic instruments adds to the remix 
characteristics, although not necessarily needed to perform a "remix," however, Sharde chose to incorporate it into this song.

When the drums enter, they play the familiar patterns heard before from Figures 3.3 and 3.4. Their role here is different, though, as they do not provide the main groove or serve as timekeepers, as in the other songs. This MIDI bass/hand-clap groove remains constant, giving the song a wider rhythmic feel and interpretation that could be influenced by hip-hop. The drums enter first at 0:30 and stop at 1:04 creating a thicker texture. They enter again at 2:02 with the same pattern again and stop for the final time at 2:37. The MIDI bass/hand-clap groove takes their role by remaining constant throughout the whole piece.

Sharde also overdubs in this recording, harmonizes with herself in her singing. From the beginning until 0:28, Sharde sings. She then plays the melody on the fife until 1:04. The drums stop playing and she sings the melody again, this time with harmony. At 1:38, the fife comes back in and the singing stops. At 1:48, she starts singing with the fife track, adding another layer to the melody, then stops with just the fife. The drums add in with the fife at 2:03, and then the texture reaches its maximum thickness when she sings with all the parts happening at once starting at 2:16. Sharde does not sing with the melody, but she freestyles the lyrical melody while the fife, drums, and MIDI bass/hand-clap rhythms play. The fife stops playing, leaving just the drums and midi track from $2: 37$ to $2: 47$. The drums drop out for the last time, and Sharde sings the lyrics twice more. The second time, the midi track stops leaving her singing, "Mama's gonna cook some Shortnin’ Bread.” 


\section{“Granny, Do Your Dog Bite?”}

\section{Overview}

This song is track number thirteen on Othar's Everybody Hollerin' Goat album and track number six on Sharde's Shawty Blues album titled "Granny." Othar's version is one minute and twenty seconds (1:20) and is the shortest recording on his album. Sharde's version is much longer at three minutes and nineteen seconds (3:19).

Similar to "Shortnin' Bread," Othar plays the fife melody and sings the lyrics to the song. The beginning starts with Othar playing the fife, but instead this time, he plays the melody of the song in a steady pulse rather than a free version heard in the songs discussed earlier. Much like Shimmy 1, Othar's notes are very thin in timbre and sound very airy. However, Othar emphasizes the rhythm within the melody indicating that the rhythm is important.

Instead of the snare being the first drum that enters, the bass drum plays its rhythm first. After two cycles of the pattern, the snare adds in with their rhythm. The rhythmic pattern for this song is different than in Figures 3.3 and 3.4. The pattern of the snare matches the rhythm found in the melody of the song, and the bass drum outlines this pattern in a unison-like fashion. The lyrics that dictate these rhythms are: "Granny do your dog bite? No, child, no. / Granny, do your dog bite? Yea, child, yea."

In Sharde's version, the song starts similarly to Othar's. Sharde plays the melody on the fife establishing a pulse, and the snare drum enters shortly after. However, the snare drum rhythm is a variation to the one in Othars version, and the bass drum does not come in at all. Instead, they stop together at 0:28, followed by four stick clicks at the same tempo, kicking off a new arrangement. After the clicks, Sharde begins to sing the melody of the song and instead of the snare and bass instruments, there is a drum set player playing a steady groove. In addition, 
Sharde has a low synth bass playing its own bass-countermelody line underneath her voice. The fife is only heard up until the 0:28 mark, where the stick clicks happen. For the rest of the song, it is just Sharde, a drum set, and the low synth bass.

Sharde sings more lines of the song than Othar does in his recording and plays the song between 84-90 bpm. This is slightly slower than Othar's version, which settles in at around 100 bpm. The drummer alternates between playing a steady grove pattern on the drum set to just the snare and the kick drum to imitate the snare and bass parts from Othar's version. However, the rhythms played are altered with the accents moving around creating more syncopation within the pattern.

\section{Description}

In Othar's version, there are only four primary pitches stretching nearly an octave between C\#6 and B6 (Figure 3.12). The "tonic" and most prevalent note played throughout the song is on the pitch E6.

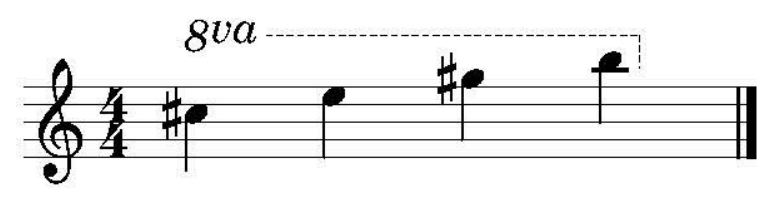

Figure 3.12 “Granny" Othar's Pitch Set

The melody of this song is much more rhythmic. The drums take a on a different role in Othar's recording to mimic the rhythm of the melody rather than having their own independent part like seen in the previous songs. The rhythm the snare plays is the same rhythm of the lyrics that Othar sings and plays on the fife (Figure 3.13). 


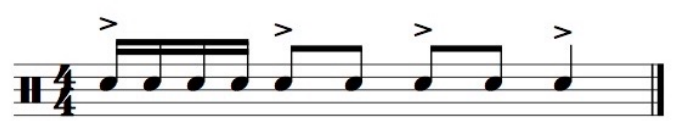

Figure 3.13 "Granny" Snare Rhythm

The words that Othar sings are, "Granny will your dog bite? No, child, no. / Granny will your dog bite? / Yea, child, yea." The first half of the lyrics fits perfectly in one measure with the rhythm played by the snare. The rhythm repeats with the second half of the lyrics He replaces the word "do" from the title of the song to "will" in the lyrics (Figure 3.14).

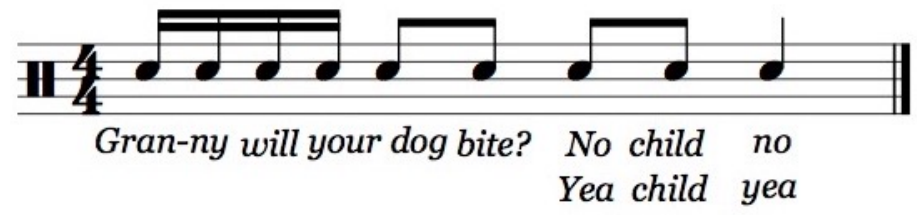

Figure 3.14 "Granny" Lyric Rhythm

As mentioned earlier, the bass drum plays a slightly different role than in the previous recordings. Rather than the snare entering first, the bass drum does. When the bass drum enters, it plays a different rhythm than the snare, adding a little syncopation. However, once Othar starts singing at 0:24 seconds, the part changes to match the snare as seen in Figure 3.13. The bass drum rhythm that is played at the beginning can be seen in Figure 3.15 below.

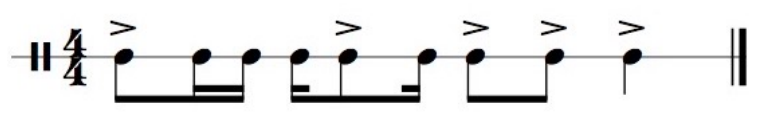

Figure 3.15 "Granny" Bass Rhythm 
From 0:46 until the end, Othar plays the melody again on the fife. On the previous recordings, Othar ends every song on the same way. The fife and drums stop together at the same time. However, in this recording, you can hear that Othar stops, and the drums continue to play the rhythm. The snare and bass play the pattern once together, and then the snare is left alone playing the pattern once more. After the snare drummer stops, you can hear the laughter as they missed the cue.

In Sharde's version, she only plays the fife for the first 0:28. She uses the same number of notes as Othar, however, they are in a lower range from pitches C6 to A6 (Figure 3.16).

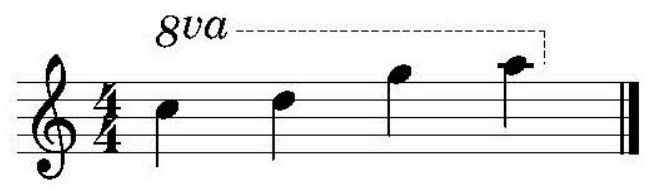

Figure 3.16 "Granny" Sharde Pitch Set

Sharde also changes the rhythm from Othar's version in Figure 3.14. Othar's melody was more articulate, thin, and airy and followed the melody of the song. Sharde's version uses a combination of slurs and tonguing articulations with a fuller tone. She does not play the same rhythm as Othar, nor does she perform the same melody. However, since she only plays the fife for the first 0:28 of the song, this can be seen as an introductory melody. Once she begins to sing, the melody of the song is heard. In Figure 3.17, I have transcribed the rhythm and melody that Othar plays on the fife in his recording. In Figure 3.17a, I have done the same with Sharde's recording at the beginning of her recording. 


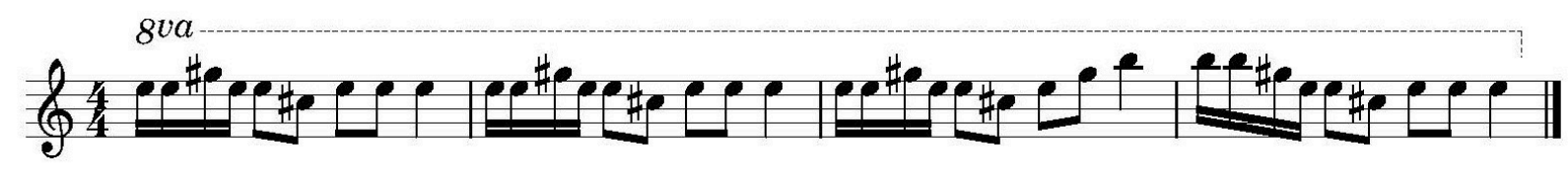

Figure 3.17 "Granny" Othar Melody

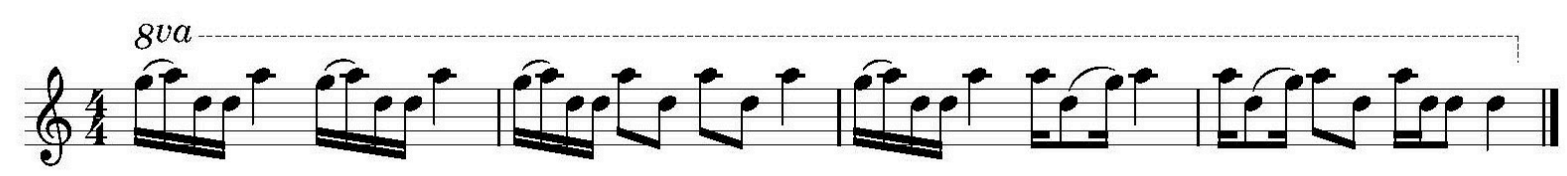

Figure 3.17a “Granny" Sharde Intro Melody

The snare drum enters at $0: 12$ to outline the rhythm she plays on the fife. The snare drum plays a two-measure pattern with slight variations. The core rhythm that is played is seen below in Figure 3.18.

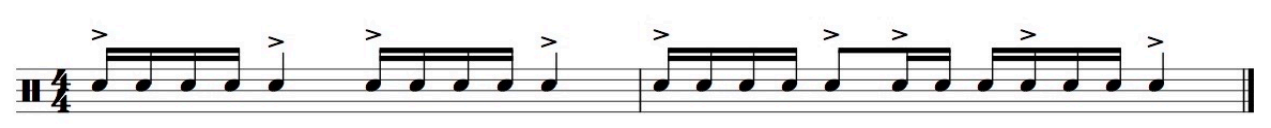

Figure 3.18 “Granny" Sharde Snare Rhythm

At 0:28, the music stops, and the drummer clicks his sticks four times to count off a new section of the song. From this point on, Sharde does not play the fife and only sings. The drummer changes from the snare and bass drum patterns to a steady rock groove on the drum set. The synth bass is added in and gives a underlying bass line to accompany Sharde's singing.

Sharde starts off singing the same lyrics as Othar, but instead of "Granny, will your dog bite? / No, child, No./ Granny, will your dog bite? / Yea, child, yea," she flips the order and sings, "Granny, will your dog bite? / Yea, child, yea. / Granny, will your dog bite? / No, child, 
no." She also sings it in a different rhythm than Othar adding some syncopation. She takes the words "Yea" and "No" from the downbeat of count 3 and moves them a sixteenth note earlier to the "a" of count 2 (Figure 3.19).

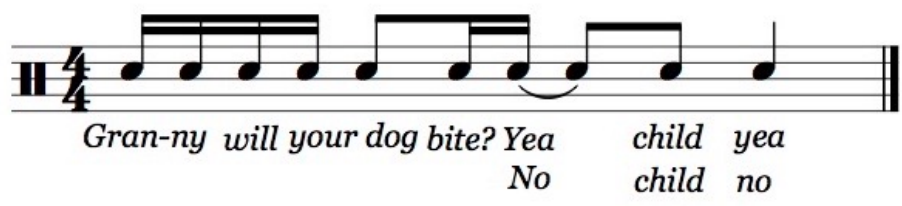

Figure 3.19 “Granny" Sharde Lyric Rhythm

From 0:32 until 0:55, Sharde sings the lyrics four times. At 0:55, Sharde sings a different set of lyrics: "Granny, will your dog bite? / Granny, is she tied? / I don't want her to bite me now. / No more Othar, dead n' gone. / He left me here to lead them on." She sings this twice and then repeats "No more Othar, dead n' gone. He left me here to lead them on" two more times as the drums and bass synth stop playing their patterns giving emphasis to these words. At 1:31, the drum set and bass synthesizer return to their groove from 0:32, and Sharde goes back to singing "Granny will your dog bite? Yea child yea," again like before. This continues until 2:05. At 2:05, the second section from earlier returns with her singing the lyrics from 0:55 seconds.

The last section of this song, starting at 2:05, features Sharde singing with the drum set player. The synth bass stops and does not return. The drum set player plays just the snare and the kick drum, moving to a more traditional Fife and Drum Blues sound. As she repeats these lyrics over and over, electronic effects added to her voice. Her words sounding echoed and phased, as it seems she has overdubbed her singing on top of herself again. However, this time, there are no harmonies, but an added layer of voices singing in unison. Her voice also pans from right to left while the voice effects are happening, adding another layer of effect. The song begins to fade out 
at 2:55 as she sings the words "said He left me here to lead them on" over and over. This fade out was not a musical dynamic decay, but one from the recording engineer that slowly pulled the fader down to end the song. This technique could represent the fading away of Othar.

\section{"In the Morning"}

\section{Overview}

This song is an original released by Sharde and The Rising Stars Fife and Drum Band in 2019. The reason to include this song in this chapter is to show how Sharde has expanded from the interpretations of Othar's songs. This song is the latest single released by Sharde, and it gives a great example of how Sharde has expanded further past the traditions of the Fife and Drum Blues genre and has created a new style of her own. The influences of electronic music, hip-hop, and $\mathrm{R} \& \mathrm{~B}$ genres are all found here in this song. The recording techniques from her previous album have been expanded upon, and reverb and other MIDI/sampled tracks are used throughout the entire song. While the fife and drum is only a small portion of what makes up this piece, they are included.

This song is 3:20 long. The fife is prominently played for only fifteen seconds near the end of the recording $(2: 32-2: 47)$. The fife melody is the melody to "Shimmy," her grandfather's favorite song.

\section{Description}

This analysis will be done in a linear fashion. I have broken this song down into five sections with a break that occurs in between the third and fourth sections. These five sections are:

1) Introduction, 0:00-0:16.

2) Theme A (main theme), 0:16-1:19.

3) Theme B (secondary theme), 1:20-2:27.

4) Theme $\mathrm{C}$ (mixing of ideas), 2:32-2:47. 
5) Theme D (climax, combination of themes), 2:48-3:20.

Section 1, the Introduction, involves a rhythmic pattern that sounds like it is played on a snare drum. However, the sound is very discreet and faintly heard. The recording engineers used many digital effects on the sound, changing the instrument's timbre but leaving the rhythm audible.

At 0:16, a high pitch cymbal-like sound falls in pitch as a result of digital effects, marking the beginning of Section 2 or "Theme A," the song's main theme. During this section, Sharde begins to sing while accompanied by piano chords. Some effects are added, such as reverb on the voice and piano, to create an open sound. Because of the effects, some of the words are not very clear. The only lyric that is discernable to this author's ear is the line "Gonna wake up in the morning, wash my face." The words after face are not as clear to understand, and no lyrics were issued with the recording's release.

At 1:04, the drum pattern from the Introduction returns. This time, the timbre is a little less discreet. The effects are still present, but it sounds more like a snare drum as the pattern becomes clearer. This builds in dynamic with other sound effects and sounds added in to push to the next section at 1:20.

Section 3, the secondary theme section, runs from 1:20 until 2:27. In this section, Sharde is no longer singing. Instead, new sounds are heard. A MIDI handclap sound is heard playing the downbeat of the pulse. A MIDI bass drop occurs every eight counts starting at 1:20. Other sounds and effects are heard in the background. Sharde adds her own sounds with a fluttertongue effect on a high note on the fife.

At 1:51, the snare drum pattern returns along with other drum-like sounds. The snare drum is even clearer than before, becoming more prominent and adding to the layers of other 
rhythms being heard. The texture and density of the rhythms and sounds begin to thicken and build in intensity, leading to a cymbal crash sound combined with a high-pitched effect that falls and decays. All the sounds stop except the handclap sound but it fades away.

From 2:28-2:31, there is a break with all the rhythm and melodic sounds. A combination of sound effects and inaudible spoken words are present. At the end, a special-effect sound is heard that sounds similar to a record or tape recording slowly stopped and then started again. After that effect, the next section starts.

Section 4, starting at 2:32, combines all the drum sounds, rhythmic figures, and effect sounds from Sections 1 and 2. This section also features Sharde on the fife playing the familiar melody to "Shimmy She Wobble." All the sounds build in intensity both in volume and rhythm to the large climatic moment at 2:48.

Section 5, from 2:48-3:20, brings the song back to the open and relaxed feel. All rhythms and drum sounds have stopped. The piano from Section 2 returns and a high-pitched electric guitar-like sound appears with reverb and effects. The electric guitar-like sound happens three times from 2:51-3:04 and does not return. By 3:08, all sounds and effect fade off and only the piano is left. Sharde sings the line "Wash my face" one more time faintly in the distance with a snare drum, the clearest it has sounded the whole song, playing soon after. The piano and snare fades off and decays to end the piece.

\section{Conclusion}

After analyzing these pieces, the musical characteristics of Othar and Sharde have become clear. As time has passed, Sharde has incorporated more instruments and recording techniques in her songs. It is also important to note that the use of technology in Sharde's recordings has directly impacted the way Sharde interprets and interacts with her music. The 
amount technology that is available now compared to when Othar released his last album in 1997 has increased immensely. It seems that Sharde has taken full advantage of these resources to emphasize her interpretations and recreate Othar's music to present it in a new way.

Sharde holds Othar's music closely to her. His impact is very apparent in her recordings. The use of the words "He left me here to lead them on" in her recording of "Granny Do Your Dog Bite?" gives a clear indication that she is taking on the role of culture bearer in this tradition. Even with her latest original, "In the Moining," she uses Othar's favorite song "Shimmy" as the fife part in her song. Even though it is for a short amount of time, it is evident that it is intentional to keep his voice within her compositions. Sharde's musical development allows us to explore the idea of heritage in a way that can help us understand these interpretations even better. 


\section{Chapter 4}

\section{Final Thoughts}

After looking deeply at these songs and understanding the idea of heritage and folklore, I can conclude that Sharde continues to hold the traditions of her grandfather Othar Turner. Although her interpretations are different, she maintains the fundamental characteristics of his music throughout her recordings. I also want to make it clear that although Othar and Sharde's interpretations and musical choices are different, neither is "better" than the other. They are equally significant. Looking at Figure 1.1, each circle in the model that surrounds heritage has its own characteristics. However, they are all interrelated and connected. Sharde's role and relationship with Othar's music is the explanation for how she is able to maneuver within the space of these traditions. Heritage is ever changing and develops by those associated with it. This concept explains the musical decisions made by Sharde found in the musical description.

Othar's album, Othar Turner and the Afrosippi Allstars From Sengeal to Senatobia, would also be another album to apply my heritage model to. This album was released in 2000, a year before his Everybody Hollerin' Goat album. Looking into this album could also provide some interesting insight into what musical characteristics Othar valued in the Fife and Drum Blues tradition as he explored and collaborated with other musicians (Danser 2011, pp. 53-56).

Expanding upon the work of Kathleen Danser, this research provides another approach to analyzing how musical traditions are preserved and developed. This model could apply to other areas of research on how music is sustained over time as well develop a larger understanding of how heritage shapes music. There are many other ways to evaluate how heritage has been preserved and developed overtime. This document serves as just one model to approach this idea. 
Another avenue for research on this topic could be found in the book, Sustainable Futures for Music Cultures: An Ecological Perspective. In the final chapter, “Approaching Music Cultures as Ecosystems," there is a section entitled, "Measuring Sustainability." In this section, Catherine Grant proposes another model in which could be used for future study. This model is called, "The Music Vitality and Endangerment Framework." This model could potentially carry this research further (Grant and Schippers 2016, pp. 343-346).

In conclusion, I have found that isolating what causes musical traditions to change can be difficult. However, upon analyzing and comparing the musical traditions of Othar and Sharde, as well as applying the ideas of heritage and folklore scholars, it becomes clearer to understand how these comparisons relate to one another. Although traditions may change, those closely associated to the traditions ultimately define their heritage by their influences and interactions with its traditions. Therefore, as seen in the heritage model in Figure 1.1, heritage is influenced by tradition, innovation, and interpretation. 


\section{Audio Resources}

The Andrews Sisters. “Shortenin’ Bread.” Decca Records. 1938.

The Beach Boys. “Shortnin' Bread.” CBS Records. 1979.

Thomas, Sharde. "In the Morning.” By Rising Stars Fife and Drum Band. 2019. iTunes.

Thomas, Sharde. Shawty Blues. 2013. CDBaby, compact disc.

Thomas, Sharde. What Do I Do? By Rising Stars Fife and Drum Band. 2010. Compact Disc.

Turner, Othar. Everybody Hollerin' Goat. By Rising Stars Fife and Drum Band. 2001. Birdman Records, compact disc.

\section{Bibliography}

Amy Brook Snider review of William Ferris, Brenda McCallum, and Robert Penn Warren.

"Local Color: A Sense of Place in Folk Art." Material Culture (International Society for Landscape, Place \& Material Culture) 16, no. 3 (1984): 138-140.

Arts, African. "African Diaspora." African Arts (UCLA James S. Coleman African Studies Center) 10, no. 1 (October 1976): 83.

Barlow, William. "'Chocolate to the Bone": Urban Blues in the South." In Looking Up at Down: The Emergence of Blues Culture, 182-229. Temple University Press, 1989.

Brackett, David. "Preaching Blues." Black Music Research Journal (Center for Black Music Research - Columbia College Chicago and University) 32, no. 1 (2012): 113-136.

Cimbala, Paul A. "Black Musicians from Slavery to Freedom: An Exploration of an AfricanAmerican FolkElite and Cultural Continuity in the Nineteenth-Century Rural South." The Journal of Negro History (The University of Chicago Press on behalf of the Association for the Studyof African American Life and History) 80, no. 1 (1995): 15-29.

Eagle, Bob. "Directory of African-Appalachian Musicians." Black Music Research Journal (Center for Black Music Research - Columbia College Chicago and Universityof Illinois Press) 24, no. 1 (2004): 7-71.

Evans, David. "Review of Homeplace by Michael Ford." The Journal of American Folklore (American Folklore Society) 91, no. 359 (January - March 1978): 632-633.

Ferris, John Greenway review of Gravel Springs Fife and Drum by William R. American Anthropologist (Wiley on behalf of the American Anthropological Association) 75, no. 2 (April 1972): 591-592. 
"Gravel Springs Fife and Drum." American Anthropologist (Wiley on behalf of the American Anthropological Association) 75, no. 6 (December 1973): 2036.

Harrison, Rodney. 2013. Heritage : Critical Approaches. Milton Park, Abingdon: Routledge.

Lomax, Alan. The Land Where the Blues Began. 1st ed. New York: Pantheon Books, 1993.

Mahar, William J. Black Music. Vol. 12, in The New Encyclopedia of Southern Culture, edited by Bill C. Malone, 19-23. University of North Carolina Press, 2008.

Narváez, Peter. "Current Blues Recordings." The Journal of American Folklore (American Folklore Society) 104, no. 414 (1991): 509-522.

Neff, Ali Colleen, and William R. Ferris. Let the World Listen Right: the Mississippi Delta HipHop Story. Jackson, MS: University Press of Mississippi, 2009.

Palmer, Robert. "Afro-American Folk Music." The Journal of American Folklore (American Folklore Society) 89, no. 353 (July-September 1976): 377-380.

Rawls, Alex. "A First Listen to New Rising Stars Fife and Drum Band Before it Plays Jazz Fest." www.myspiltmilk.com. https://www.myspiltmilk.com/articles/a-first-listen-to-newrising-stars-fife-and-drum-band-before-it-plays-jazzfest?rq $=$ rising $\% 20$ stars $\% 20$ fife $\% 20$ and $\% 20$ drum $\% 20$ band (accessed April 25, 2020).

Review, African American. "Black Folklore Documentary." Negro American Literature Forum (African American Review (St. Louis University)) 8, no. 2 (1974): 211.

“'Rising Star' Shardé Thomas Brings Vocals \& Fife Tradition to Centrum.” Centrum. https://centrum.org/2019/04/rising-star-sharde-thomas/ (accessed April 26, 2010).

Robert Palmer review of Edmund Carpenter, Bess Lomax Hawes and AlanLomax. "Gravel Springs Fife and Drum." The Journal of American Folklore (American Folklore Society) 90, no. 356 (1977): 249-250.

Schippers, Huib, and Catherine Grant. Sustainable Futures for Music Cultures: an Ecological Perspective. New York, NY: Oxford University Press, 2016.

"Shardé Thomas propels the Rising Stars Fife \& Drum Band into a new century." Chicago Reader. https://www.chicagoreader.com/chicago/sharde-thomas-otha-turner-risings-starsfife-drum-blues/Content?oid=49625591 (accessed April 26, 2020).

Sims, Martha C, and Martine Stephens. 2005. Living Folklore : An Introduction to the Study of People and Their Traditions. Logan: Utah State University Press. 
Thomas A. Green review of several works by David Evans, Bill Ferris, Josette Ferris, Judy Peiser, and Bobby Taylor. "Gravel Springs Fife and Drum, Ray Lum: Mule Trader, Delta BluesSinger: James "Sonny Ford" Thomas, Mississippi Delta Blues." American Anthropologist (Wiley on behalf of the American Anthropological Association) 77, no. 2 (June 1975): 473-475.

Thomas, Sharde. Liner notes to What Do I Do?. Self-Published. CD. 2010.

Turner, Othar. Liner notes to Everybody Hollerin' Goat. Robert Gordon, BMR-018. CD. 2001.

Vignos, Paul. " Review of Gravel Springs Fife and Drum by Bill Ferris, Judy Peiser and David Evans." Ethnomusicology (University of Illinois Press on behalf of Society for Ethnomusicology) 17, no. 3 (September 1973): 599-601.

Wade, Stephen. The Beautiful Music All around Us: Field Recordings and the American Experience. Urbana: University of Illinois Press, 2012.

Wolfe, Charles. "Rural Black String Band Music." Black Music Research Journal, (Center for Black Music Research - Columbia College Chicago and Universityof Illinois Press) 10, no. 1 (1990): 32-35. 